\title{
Groupon's Growth And Globalization Strategy: Structural And Technological Implications Of International Markets
}

\author{
Suzaan Hughes, Monash South Africa, South Africa
}

Chantal Breytenbach, Monash South Africa, South Africa

\begin{abstract}
Groupon is the fastest growing company in the daily deal social e-commerce arena. For this reason, their growth and globalization strategy is of particular interest to any researcher or investor interested in understanding this industry and its potential future growth and development. In this first follow-up article on mergers and acquisitions as Groupon's primary growth and globalization strategy, the researchers discuss the structural and technological implications of expanding into developing international markets. The research method utilized in this article was a case study. In a previous article, the researchers evaluated Groupon's success in utilizing $M \& A$ 's as its growth and globalization strategy, by applying Ruess and Voelpel's (2012) Post Merger Integration (PMI) Scorecard. The factors discussed under the PMI Scorecard included strategic, structural, personnel, cultural and stakeholder integration. In this article, the researchers take an in-depth look at structural and technological implications of acquisitions made by Groupon in developing international markets.
\end{abstract}

A well-developed transport and communications infrastructure network is "a pre-requisite for the access of less-developed communities to core economic activities and services" (Schwab, Sala-iMartin \& Greenhill, 2011). Effective economies therefore depend on sufficient and uninterrupted electricity supply that would enable unimpeded business functioning. The ability to adopt existing technologies, specifically information and communication technologies (ICT's) is indicative of a country's level of technological readiness. In countries with limited access to the Internet, mobile broadband, smartphones and social media (like Facebook), Groupon has not managed to build an extensive database of customers. Although they may have reached a particular level of customer saturation in the USA, it cannot be argued that they have succeeded in building the same extensive network of customers in other markets, which calls into question the spending on acquisitions in other markets in order to expand their global reach.

Keywords: Daily Deal Sites; Groupon; Mergers and Acquisitions; Globalization; Structural Integration; Technological Implications of Acquisitions in International Markets

\section{INTRODUCTION}

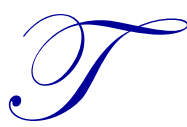

he convergence of traditional and electronic business models, as well as traditional and new business practices, are changing the face of global business as we know it. Electronic business models provide a particular opportunity for content, community and commerce to converge. Group buying daily deal sites are the result of a convergence between content sites and social networks. Daily deal sites allow individuals to leverage bargaining power as a collective in order to obtain discounted deals on local products, services and experiences. These local discounted deals are distributed as electronic coupons via e-mail and mobile channels to subscribers of websites like Groupon (Beukes \& Hughes, 2012, p. 1; Hughes \& Beukes, 2012, p. 922). Daily deal social group buying sites are of interest from a strategy, as well as a development and growth perspective, as they challenge traditional paradigms on how to build a profitable business (Hughes \& Beukes, 2012, p. 922). Groupon is the fastest growing and biggest daily deal social group buying site (Hughes \& Beukes, 2012, p. 924). 
"Conventional strategic wisdom dictates that a business first establishes itself as successful and profitable in its home market before exploring growth on a global stage" (Beukes \& Hughes, 2012, p. 114). Groupon has ventured beyond its domestic market almost from the start by employing an aggressive growth and globalization strategy fuelled largely by mergers and acquisitions. Since its inception in 2008, Groupon has acquired twenty-eight companies across the USA and globally. An intentional growth and globalization strategy would imply a wellthought-through acquisition of the most viable competitors in each market. Looking at the strategic fit between Groupon and its acquisitions in terms of its intended future direction, there is evidence of hasty and ill-conceived acquisitions of companies that did not necessarily present the most viable option. In a previous article, the researchers discussed how Groupon is utilizing mergers and acquisitions as their primary growth and globalization strategy for two major reasons: (1) to acquire new markets and customers and (2) to strengthen their underlying technology.

In evaluating the effectiveness of Groupon's growth and globalization strategy, the researchers utilized the integration factors identified by Ruess and Voelpel (2012) in the development of their Post-Merger Integration (PMI) Scorecard for balancing post-merger integration. These factors included integration on the following levels: strategic, structural, personnel, cultural and stakeholders. Strategic integration considers the strategic direction of the companies that are about to be integrated (Ruess \& Voelpel, 2012, p. 79). An acquiring company has to consider how a newly acquired company would fit into the strategic direction the acquiring company would like to pursue. Structural integration complements strategic integration. The aim is to establish meaningful and strategically adequate organizational structures and processes for the newly integrated entity (Ruess \& Voelpel, 2012, p. 79). Furthermore, structural integration is directly dependent on existing infrastructure and technology for the successful pursuit of the newly integrated business. When the acquiring company acquires a company outside its national borders, the infrastructure and level of technological advancement of the foreign market should be evaluated to ensure the business will be able to pursue its new intended strategy. Personnel integration requires consideration of the employees who will be retained in the newly merged entity as well as job requirements, skills development, incentive systems etc. (Ruess \& Voelpel, 2012, p. 79). Cultural integration involves the merging of two, often different, organisational cultures into a newly integrated organisational culture that incorporates the most important values held by the original separate entities (Child, 2000; Salama, Holland \& Vinten, 2003). Lastly, stakeholder integration demands consideration of all the external stakeholders that will be affected by the merger or acquisition. Stakeholders include customers, business partners, governments and union representatives (Ruess \& Voelpel, 2012, p. 79).

In this follow-up article, the researchers further investigate Groupon's expansion into international markets through the acquisition of imitator companies with the specific purpose of acquiring new customers and expanding their international market share. When multi-national organisations enter international markets that are structurally very different from their own, these new markets could present obstacles to effective business functioning. Multinational organisations venturing into new markets, especially developing markets, need to carefully consider whether the existing infrastructure in those markets is conducive for effective business functioning. When the multinational's core business depends on information technology for successful functioning, the level of technological advances and Internet saturation and/or access to the Internet become important considerations before establishing an international branch in that particular international market. The U.N. recently offered a sobering statistic. A 2013 study found that more people have access to cell phones than toilets (Wang, 2013). This means that even if customers have access to mobile phones, this does not mean that the country has the necessary infrastructure to support new and growing e-commerce and/or foreign multi-national companies wanting to invest there. For this reason, the researchers will not only consider the technological implications of Groupon's acquisitions, but also the structural considerations necessary for successful expansion of the business into international markets that might be significantly different from their home market.

\section{RESEARCH PURPOSE}

This study aims to provide insight and critical reflections on the structural and technological implications for multi-national organisations who wish to expand their businesses into new international (and often developing) markets. In this case study, the researchers consider the structural and technological factors that impacted on Groupon's post-merger structural integration in international developing countries. 


\section{RESEARCH DESIGN \& METHODOLOGY}

The research paradigm for this study was qualitative; in particular, an instrumental case study (Stake, 2005). Case studies are aimed at discovering meaning and gaining heuristic understanding (Eriksson \& Kovalainen, 2008, p. 117; Merriam, 2009, p. 39). Case studies are used to test, illustrate or generate theory, or alternatively to identify the sources of problems or solutions to problems (Gomm, Hammersley \& Foster, 2000). A case study is, in essence, a problem-centric approach to research. This case study, in particular, will be used to discuss the structural considerations affecting the level of competitiveness of international markets that Groupon has ventured into as well as the technological factors that indicate the level of online activity in these countries. To gain a clear picture of the problem at hand, the case must be investigated from many angles by gathering data from different sources (HesseBiber, \& Leavy, 2011, p. 265), such as documentation, archival records, physical artefacts, etc. (Yin, 2008). The case of Groupon is about an online entity situated within a milieu embedded in a number of international contexts. Groupon has expanded its business into these international markets without due consideration for the structural and technological factors that would impact on successful post-acquisition integration and business operation.

There are different perspectives on the nature of case studies. One school of thought would argue that case studies are too particularistic and thus present a limitation to the research strategy as the findings cannot be generalised (Merriam, 2009, p. 43). However, in this particular study, the data evaluated for this case study has transferability. Although the researchers are looking at Groupon in particular, their presence in different countries is being analysed in light of the specific structural and technological differences. These differences would affect any other high-tech company that would want to enter that market; hence, the data and analyses become transferable to other contexts and other types of companies.

\section{LITERATURE REVIEW}

Mergers and acquisitions (M\&A's) are considered a natural way of expansion for growing companies as many organisations have managed to expand their businesses successfully through the acquisition of smaller organisations (Chakrabarti et.al., 1994; Collan \& Kinnunen, 2011, p. 118; Hitt, Harrison \& Ireland, 2000; Ooghe, Van Laere and De Langhe, 2006, p. 223; Ruess \& Voelpel, 2012, p. 78). Before the global recession, there was a sharp rise in the number of international mergers and acquisitions. The average dollar value of M\&A's between 2000 and 2008 was US $\$ 648.9$ billion compared to US $\$ 253.8$ billion between 1990 and 1999 (Chakrabarti et.al., 1994, p. 47; Edwards \& Edwards, 2012, p. 505; United Nations, 2009). It seems, therefore, that M\&A's have become a popular form of corporate development (Cartwright and Schoenberg, 2006). In fact, M\&A's have become the dominant strategy through which multinational organisations expand into other countries (Edwards \& Edwards, 2012, p. 505). The technology sector is no exception to this rule.

This is evident from Groupon's rapid expansion into foreign markets with the purpose of acquiring new customers and expanding its international market share. Since 2010, Groupon has acquired 13 imitator companies in foreign markets. None of these acquisitions were hostile take-overs. In fact, in some markets - for example, South Africa - the imitator company approached Groupon and in other markets, one imitator was leveraged into several neighbouring and related markets - for example, ClanDescuento in Chile (Beukes \& Hughes, 2012).

Despite their popularity, M\&A's have produced mixed results for stakeholders (Amihud, Dodd \& Weinstein, 1986; Fowler and Schmidt, 1988; Lubatkin, 1987; King, Dalton, Daily \& Covin, 2004; Lubatkin and O'Neil, 1987). On the positive side, some of the potential benefits of M\&A's include increased market share, improved efficiency, expansion of research and development efforts, organisational growth (Bradley, Desai \& Kim, 1983; Bruner, 2004a, 2004b; DePamphilis, 2009; Krishnamurti \& Vishwanath, 2008; Pablo \& Javidan, 2004; Walker, 2000), risk reduction through shared costs of risks, entrance to new markets, and stock market returns for the acquiring company (Beukes \& Hughes, 2012; Chakrabarti, Hauschildt, \& Sueverkruep, 1994; Hagedoorn \& Duysters, 2002; Hitt, Hoskisson, Johnson, \& Moesel, 1996; Ikedo, \& Doi, 1983; Oster, 1994). However, on the negative side, the failure rate of M\&A's is very high (Ruess \& Voelpel, 2012, p. 78). Studies have shown that M\&A's deliver disappointing results more often than not (Edwards \& Edwards, 2012; Habelian, Devers, McNamara, Carpenter \& Davison, 2009) since between 50 and 80 percent of all mergers do not achieve their strategic, operational or financial goals (Ruess \& Voelpel, 2012). Additionally, the realized corporate growth of the acquired company, after the fact, remains heavily contested (Ooghe et al., 2006, p. 223). Unsuccessful post-merger 
integration has also been linked to high staff turnover (Napier, 1989) and poor post-merger performance (Teerikangas \& Very, 2006; Weber, 1996).

Post-merger integration in a foreign market presents additional challenges since the acquirer also has to take cognisance of the structural and technological factors that affect effective business functioning in that particular market. Before an organisation expands its business into foreign markets, it needs to consider the political and economic climate of the foreign market, the legislation and laws that will affect is operations, as well as the national culture and socio-cultural factors that affect business in that particular market. When looking at the economic viability of establishing another branch in a foreign market, the existing infrastructure and level of global competitiveness of the foreign market determines the level of expected return on investment.

The World Economic Forum publishes an annual Global Competitiveness Report where they rank different countries in the world based on the quality of their infrastructure to determine their level of international competitiveness. The 2013 report features a record number of 144 economies and thus represents the most comprehensive assessment of its kind. The report contains a detailed profile of every economy listed and measures each economy's competitiveness. Since 2005, the World Economic Forum has based its competitiveness analysis on the Global Competitiveness Index (GCI), a comprehensive tool that measures the microeconomic and macroeconomic foundations of national competitiveness (Sala-i-Martín \& Artadi, 2004).

The World Economic Forum defines competitiveness as "a set of institutions, policies and factors that determine the level of productivity of a country". The level of productivity, in turn, determines the level of prosperity a particular economy is able to achieve (Schwab \& Sala-i-Martin, 2012, p. 4). Prosperity would be indicative of consumer buying power and the possible rates of return on investments. Thus, the higher a country's competitive ranking, the more productive the economy and the more likely the economy is to yield sustainable growth and consumers are more likely to invest in e-commerce. Since the World Economic Forum's Global Competitiveness Report represents the most robust and comprehensive evaluation of its kind, it provided the foundation for the analysis in this article.

\section{FINDINGS AND DISCUSSION}

Infrastructure refers to the fundamental facilities and systems serving a country, city or area such as transportation systems, power plants and education etc. (Dictionary.com). In other words, it is the facilities and services necessary for an economy to function (Sullivan \& Sheffrin, 2003 p. 474). From a functional perspective, infrastructure enables the production of products and the development of services, as well as the distribution of these finished products and services to different target markets. It represents the physical and organisational structures that should be in place for societies, industries and businesses to exist and to function. Modernisation of infrastructure seems critical for future competitiveness on a global scale (Urban Land Institute and Ernst and Young, 2011). There are various structural factors that contribute to the development of a country's infrastructure such as roads, railways, airways, transportation and logistics, water supply, sewers, electrical grids, and communication channels, etc.

The structural factors that will be discussed in this particular case study include: 1) the quality of electricity supply, 2) the number of fixed telephone lines, and 3) the number of mobile telephone subscriptions, as these factors are all indicative of sufficient access to websites and possible online activity. Of course, there are other factors that contribute to a country's overall infrastructure - such as roads, railways, airways, logistics, water supply, etc. However, for purposes of this article, the focus will be on the factors necessary for e-commerce. For these factors to be present at a particular level within a country, there would have to be an extant and developed broader infrastructure that includes roads and logistics. For global business success, a well-developed transport and communications infrastructure network is "a pre-requisite for the access of less-developed communities to core economic activities and services" (Schwab, Sala-i-Martin \& Greenhill, 2011).

As mentioned above, Groupon has acquired 13 imitator companies in foreign markets. In some instances, imitators have been leveraged to allow Groupon to expand their global reach into neighbouring countries. Groupon currently has a presence in the following geographical regions: Africa (one country), Asia (nine countries), the Middle East (two countries), Europe (three countries), the European Union (14 countries), North America (three 
countries), Latin America (six countries) and Oceania (two countries). Table 1 illustrates the structural considerations affecting the global competitiveness of the countries that Groupon operates in.

Table 1: Structural Considerations Affecting the Global Competitiveness of Countries in Which Groupon Operates

\begin{tabular}{|c|c|c|c|c|c|c|c|}
\hline Country & $\begin{array}{l}\text { Global } \\
\text { Rank } \\
1 / 144\end{array}$ & $\begin{array}{c}\text { Global } \\
\text { Score } \\
(1-7)\end{array}$ & $\begin{array}{c}\text { Stage Of } \\
\text { Development } \\
(1-3)\end{array}$ & $\begin{array}{c}\text { Quality Of } \\
\text { Overall } \\
\text { Infrastructure } \\
(1-7) \\
\end{array}$ & $\begin{array}{c}\text { Electricity } \\
\text { Supply } \\
(1-7)\end{array}$ & $\begin{array}{c}\text { Fixed Telephone } \\
\text { Lines } \\
\text { (Per } 100 \text { People) }\end{array}$ & $\begin{array}{c}\text { Mobile } \\
\text { Telephone } \\
\text { Subscriptions } \\
\text { (Per 100 People) }\end{array}$ \\
\hline \multicolumn{8}{|l|}{ Africa } \\
\hline South Africa & 52 & 4.37 & Stage 2 & 4.5 & 3.9 & 8.2 & 126.8 \\
\hline \multicolumn{8}{|l|}{ Asia } \\
\hline China & 29 & 4.83 & Stage 2 & 4.3 & 5.2 & 21.2 & 73.2 \\
\hline Hong Kong & 9 & 5.41 & Stage 3 & 6.5 & 6.8 & 61.1 & 209.6 \\
\hline India & 59 & 4.32 & Stage 1 & 3.8 & 3.2 & 2.6 & 72.0 \\
\hline Indonesia & 50 & 4.40 & Stage 2 & 3.7 & 3.9 & 15.9 & 97.7 \\
\hline Japan & 10 & 5.40 & Stage 3 & 5.9 & 5.9 & 51.1 & 102.7 \\
\hline Malaysia & 25 & 5.06 & Stage 2 & 5.4 & 5.9 & 14.7 & 127.0 \\
\hline Singapore & 2 & 5.67 & Stage 3 & 6.5 & 6.7 & 38.9 & 149.5 \\
\hline South Korea & 19 & 5.12 & Stage 3 & 5.8 & 6.0 & 60.9 & 108.5 \\
\hline Taiwan & 13 & 5.28 & Stage 3 & 5.5 & 6.3 & 72.7 & 124.1 \\
\hline \multicolumn{8}{|l|}{ Middle East } \\
\hline Israel & 26 & 5.02 & Stage 3 & 5.0 & 5.5 & 46.3 & 121.7 \\
\hline U.A.E & 24 & 5.07 & Stage 3 & 6.4 & 6.4 & 23.1 & 148.6 \\
\hline \multicolumn{8}{|l|}{ Europe } \\
\hline Norway & 15 & 5.27 & Stage 3 & 5.2 & 6.5 & 42.7 & 116.8 \\
\hline Russia & 67 & 4.20 & Stage 2 & 3.5 & 4.3 & 30.9 & 179.3 \\
\hline Turkey & 43 & 4.45 & Stage 2 & 5.3 & 4.6 & 20.7 & 88.7 \\
\hline \multicolumn{8}{|c|}{ European Union } \\
\hline Belgium & 17 & 5.21 & Stage 3 & 5.9 & 6.6 & 43.1 & 116.6 \\
\hline Finland & 3 & 5.55 & Stage 3 & 6.5 & 6.6 & 20.1 & 166.0 \\
\hline France & 21 & 5.11 & Stage 3 & 6.4 & 6.7 & 55.9 & 105.0 \\
\hline Germany & 6 & 5.48 & Stage 3 & 6.2 & 6.4 & 63.0 & 132.3 \\
\hline Greece & 96 & 3.86 & Stage 3 & 4.5 & 5.2 & 49.9 & 106.5 \\
\hline Ireland & 27 & 4.91 & Stage 3 & 5.2 & 6.5 & 45.2 & 108.4 \\
\hline Italy & 42 & 4.46 & Stage 3 & 3.9 & 5.8 & 34.6 & 151.8 \\
\hline Netherlands & 5 & 5.50 & Stage 3 & 6.2 & 6.8 & 43.5 & 115.4 \\
\hline Poland & 41 & 4.46 & Stage 2 & 4.0 & 5.5 & 18.2 & 128.5 \\
\hline Portugal & 49 & 4.40 & Stage 3 & 6.2 & 6.3 & 42.3 & 114.9 \\
\hline Romania & 78 & 4.07 & Stage 2 & 2.8 & 4.2 & 21.9 & 109.2 \\
\hline Spain & 36 & 4.60 & Stage 3 & 5.8 & 6.1 & 42.3 & 114.2 \\
\hline Sweden & 4 & 5.53 & Stage 3 & 5.8 & 6.6 & 48.7 & 118.6 \\
\hline UK & 8 & 5.45 & Stage 3 & 5.6 & 6.7 & 53.2 & 130.8 \\
\hline \multicolumn{8}{|c|}{ North America } \\
\hline Canada & 14 & 5.27 & Stage 3 & 6.0 & 6.6 & 47.9 & 75.3 \\
\hline Mexico & 53 & 4.36 & Stage 2 & 4.4 & 4.6 & 17.1 & 82.4 \\
\hline USA & 7 & 5.47 & Stage 3 & 5.6 & 6.0 & 47.9 & 105.9 \\
\hline \multicolumn{8}{|c|}{ Latin America } \\
\hline Argentina & 94 & 3.87 & Stage 2 & 3.4 & 3.5 & 24.9 & 134.9 \\
\hline Brazil & 48 & 4.40 & Stage 2 & 3.4 & 4.9 & 21.9 & 123.3 \\
\hline Chile & 33 & 4.65 & Stage 2 & 5.4 & 5.4 & 19.5 & 129.7 \\
\hline Columbia & 69 & 4.18 & Stage 2 & 3.4 & 5.1 & 15.2 & 98.5 \\
\hline Peru & 61 & 4.28 & Stage 2 & 3.4 & 4.8 & 11.1 & 110.4 \\
\hline Puerto Rico & 31 & 4.67 & Stage 3 & 5.0 & 5.1 & 22.1 & 83.0 \\
\hline \multicolumn{8}{|l|}{ Oceania } \\
\hline Australia & 20 & 5.12 & Stage 3 & 5.2 & 6.3 & 46.6 & 108.3 \\
\hline New Zealand & 23 & 5.09 & Stage 3 & 4.9 & 6.0 & 42.6 & 109.2 \\
\hline \multicolumn{8}{|c|}{$\begin{array}{l}\text { Global Competitiveness score (1-7): Aggregate score, } 1=\text { low development and } 7=\text { high development; Stage of development: Stage } 1=\text { Factor } \\
\text { driven, Stage } 2=\text { Efficiency driven, Stage } 3=\text { Innovation driven; Quality of overall infrastructure }(1-7): 1=\text { Extremely underdeveloped, } 7= \\
\text { Extensive and Efficient by International standards; Electricity Supply }(1-7): 1=\text { insufficient and suffers frequent interruptions, } 7=\text { sufficient and } \\
\text { reliable; Fixed telephone lines: Number of active fixed telephone lines per } 100 \text { population. }\end{array}$} \\
\hline
\end{tabular}


In Table 1, the global competitiveness score for each country Groupon operates in is summarised by geographical region. The first indicator of global competitiveness is the country's ranking. The 2012-2013 Global Competitiveness Report evaluated 144 countries. Thus, Table 1 indicates each country's rank out of 144 on the list. Each country is assigned a global score that is aggregated into a single index representing the twelve pillars of development that the report measures - institutions, infrastructure, macro-economic environment, health and primary education, higher education and training, goods market efficiency, labour market efficiency, financial market development, technological readiness, market size, business sophistication, and innovation. Therefore, the global rank indicates how successfully a country has managed to develop in light of all twelve of the pillars. A score of one indicates a low level of development and a score of seven indicates a high level of development.

Whilst all these pillars are important, not all of them would require the same level of attention in each country. The pillars that require the most attention would depend on the stage of development the country is in (see column four of Table 1). There are three stages of development:

1. Stage 1 indicates factor-driven economies that are primarily based on unskilled labour and natural resources. The key pillars to focus on in a factor-driven economy include institutions, infrastructure, macroeconomic environment, and health and primary education as these factors represent the bases from which all other economic activity would stem.

2. Stage 2 represents efficiency-driven economies which are focused on developing more efficient production processes, increasing product quality, managing prices, and increasing wages. Efficiency-enhancing pillars are higher education and training, goods market efficiency, labour market efficiency, financial market development, technological readiness, and market size.

3. Stage 3 represents innovation-driven economies where businesses have to focus on developing new and unique products using sophisticated production processes as this is the only way they would be able to sustain high wages and higher standards of living. Therefore, the innovation-driven pillars include business sophistication and innovation.

The USA would be an example of a Stage 3 economy that is innovation-driven explaining, to an extent, their leadership in the development of e-commerce business models, like the business model of Groupon. Although an innovation-driven economy, like the USA, is able to sustain the complexities of e-commerce business models, these business models might not be sustainable in countries that are in a different stage of development. An evaluation of the different regions that Groupon has a presence in shows that some of the countries are in Stage 1 or 2 of development, which means that these economies are not able to sustain the complexities inherent in ecommerce and the execution of business through social group buying.

Effective economies depend on sufficient and uninterrupted electricity supply that would enable unimpeded business functioning. Furthermore, a solid and extensive telecommunications network allows for rapid and free-flow of information. This increases overall economic efficiency by ensuring effective business decision-making based on relevant and current information available to the right people at the right time (Schwab et al., 2011). Looking at the Middle East, Europe, the European Union (excluding Poland), North America and Oceania, these countries are all in Stage 3 of economic development and are therefore able to sustain e-commerce and social group buying business models. However, countries in Africa, Asia and Latin America are not in the same stage of development. Some of Groupon's most significant post-acquisition challenges arise from these three regions. In Africa, Groupon has a presence in only one country - South Africa.

The supply and access to electricity in South Africa has not been in line with the growth of the population and associated demand for electricity. Various regions of South Africa still do not have a consistent supply of electricity. In 1996, only 58\% of South Africans had access to electricity. By 2001, access had increased to approximately $70 \%$ of the population (Zuma, 2011). However, this still means that $30 \%$ of the population do not have access to electricity and the massive increase in energy supply has placed additional pressure on the national electricity grid. Since 2008, South Africa has battled with an inconsistent supply of electricity and has faced power cuts which have cost the economy US\$5.5 billion (Styan, 2013). The unequal distribution of electricity in South Africa also means that some provinces and cities do not have access to the Internet. This limits Groupon's operations to just four major cities - Johannesburg, Cape Town, Pretoria and Durban. Groupon, therefore, has 
limited market share in South Africa with most of the daily deals being advertised in Johannesburg - the largest metropolitan city based on population and access to employment.

In Asia, India is currently in Stage 1 of economic development, representing the largest disparity between Groupon's home country and any of the foreign markets they have entered. More than 400 million people in India do not currently have access to electricity. Quality of life in this country is limited by access to electricity and clean fuels. On an average day, there is a nine percent shortfall of electricity supply which results in "lost" annual economic growth of approximately 1.2 percent (Randall, 2012). Similar to South Africa, the unequal distribution of electricity supply means that Groupon only has access to markets in a few major cities - Ahmedabad, Bangalore, Chandigarh, Chennai, Delhi, Hyderabad, Jaipur, Kolkata, Mumbai, Nagpur and Pune (Wauters, 2011).

The quality of overall infrastructure (i.e. the second pillar of global competitiveness) for each country indicates the location of economic activity as well as the kind of sectors and industries that can flourish in any given country. Well-developed infrastructure reduces the distance between different regional markets and integrates these markets into one national market, as well as connecting it to other countries and regions (Schwab \& Sala-i-Martin, 2012, p. 5). This means that e-commerce can only flourish in an integrated and well-connected economic market with a stable transport and communications infrastructure network. The communications infrastructure is reflected in its electricity supply, number of fixed telephone lines and mobile phone subscriptions.

Business operations and Internet access can be hampered or helped by access to fixed telephone lines. The effectiveness of an Internet connection depends on latency and throughput. Latency affects the speed of a network. It refers to any kind of delay that could typically be incurred during the processing of network data (Mitchell, 2013). The bandwidth size of any Internet connection is dependent on the quality of the fixed telephone lines and the quality of network cables used in these telephone lines. Throughput is defined as "the amount of raw material that can be processed at any given time" (Dictionary.com, 2013). Again, the bandwidth of an Internet connection determines the rate of throughput of data and determines the speed at which e-commerce transactions can be processed.

Looking at the number of fixed telephone lines per 100 people, two countries (South Africa and India) in Table 1 have less than ten fixed telephone lines per 100 people. Furthermore, nine countries (China, Indonesia, Malaysia, United Arab Emirates (U.A.E.), Finland, Poland, Romania and Mexico) have less than 25 fixed telephone lines per 100 people. The lack of fixed telephone lines does not, in itself, present an obstacle if other infrastructure makes up for it; for example, as is the case with Finland. With widely dispersed communities and no dominant national provider of fixed land lines, mobile phones (in particular, Nokia) developed much quicker in this country. In Finland's case, overall infrastructure balanced out because the pace of development in other areas compensated for the lack of development of fixed telephone lines. Nokia's emergence in the early 1990's as one of the world's leading mobile-phone makers dramatically influenced Finland's prosperity, contributing four percent to the country's overall GDP. Finland became a European technology hub and the economy has tripled in size between 1993 and 2008 (Lawton, 2011).

Finland is a Stage 3 economy. Since they are innovation-based, they can compensate for infrastructure in a way that Stage 1 and 2 countries cannot. Finland has 166 mobile phone subscriptions per 100 people, indicating the shift to this type of technology to support their communication needs. In countries like South Africa, India, Indonesia, Poland, Romania and Mexico, the infrastructure is not developed enough to compensate for the lack of fixed telephone lines, resulting in an arrearage in e-commerce, in particular. From the markets that Groupon has entered (or leveraged into), there are 15 countries that have not reached Stage 3 of economic development yet and would thus not be able to sustain e-commerce business activities in the long run.

The ability to adopt existing technologies, specifically information and communication technologies (ICT's), is indicative of a country's level of technological readiness. ICT access and usage are key enablers of a country's overall technological readiness and are therefore pivotal for continued growth and productivity, especially for e-commerce (Schwab \& Sala-i-Martin, 2012, p. 6). Technological readiness is a pre-cursor for innovation as the level of technological readiness of a particular country determines its ability to innovate in Stage 3 . With the exception of U.A.E. and Finland, all the other countries identified above as having limited Internet connectivity also scored low on technological readiness - with a score of below 5 out of 7 (Schwab \& Sala-i-Martin, 2012). 
The technological factors that emanate from the structural factors include Internet access and saturation, smart phone users and registered Facebook users. Technological factors indicate online activity using various platforms and thus potential participation in e-commerce and social group buying. Although there are more social media platforms, Facebook seems to have the highest global saturation and would therefore provide an accurate reflection of participation on online social media platforms. Additionally, until recently, most of Groupon's advertising expenditure was on Facebook (Bercovici, 2012), providing a clear link to potential Groupon customers. Table 2 represents a summary of the technological factors that point to online activity in the countries that Groupon operates in. 
Table 2: Technological Factors Indicating Online Activity in the Countries That Groupon Operates In

\begin{tabular}{|c|c|c|c|c|c|c|c|c|}
\hline Country & $\begin{array}{l}\text { Population } \\
\text { Estimate } \\
(2011)\end{array}$ & $\begin{array}{c}\text { Internet } \\
\text { Access }\end{array}$ & $\begin{array}{c}\text { Internet Penetration } \\
\text { (\% Of The } \\
\text { Population) }\end{array}$ & $\begin{array}{c}\text { Internet } \\
\text { Bandwidth } \\
\text { Speed (Kb/S) }\end{array}$ & $\begin{array}{l}\text { Smartphone } \\
\text { Users }\end{array}$ & $\begin{array}{c}\text { Smartphone } \\
\text { Penetration }(\% \\
\text { Of The } \\
\text { Population) } \\
\end{array}$ & $\begin{array}{c}\text { Registered } \\
\text { Facebook Users } \\
\text { (31 March 2013) }\end{array}$ & $\begin{array}{c}\text { Facebook } \\
\text { Penetration }(\% \\
\text { Of The } \\
\text { Population) } \\
\end{array}$ \\
\hline \multicolumn{9}{|l|}{ Africa } \\
\hline South Africa & $49,004,031$ & $6,800,000$ & $13.90 \%$ & 18.9 & $8,700,000$ & $17 \%$ & $5,534,160$ & $11.29 \%$ \\
\hline \multicolumn{9}{|l|}{ Asia } \\
\hline China & $1,336,718,015$ & $513,100,000$ & $38 \%$ & 2.7 & $77,000,000$ & $6 \%$ & 597,520 & $0.04 \%$ \\
\hline Hong Kong & $7,122,508$ & $4,894,914$ & $68.70 \%$ & 964.6 & $4,900,000$ & $61 \%$ & $3,746,460$ & $54.31 \%$ \\
\hline India & $1,189,172,906$ & $121,000,000$ & $10.20 \%$ & 5.4 & $33,200,000$ & $3 \%$ & $62,963,440$ & $5.37 \%$ \\
\hline Indonesia & $245,613,043$ & $55,000,000$ & $22.40 \%$ & 7.2 & $18,100,000$ & $8 \%$ & $47,165,080$ & $19.41 \%$ \\
\hline Japan & $126,475,664$ & $101,228,736$ & $80 \%$ & 23.1 & $18,100,000$ & $14 \%$ & $12,911,300$ & $10.14 \%$ \\
\hline Malaysia & $28,728,607$ & $17,723,000$ & $61.70 \%$ & 10.7 & $5,200,000$ & $19 \%$ & $13,085,000$ & $46.28 \%$ \\
\hline Singapore & $4,740,737$ & $3,658,400$ & $77.20 \%$ & 547.1 & $4,400,000$ & $90 \%$ & $2,757,720$ & $58.66 \%$ \\
\hline South Korea & $48,754,657$ & $40,329,660$ & $82.70 \%$ & 17.2 & $16,400,000$ & $34 \%$ & $8,286,920$ & $17.11 \%$ \\
\hline Taiwan & $23,071,779$ & $16,174,000$ & $70 \%$ & 34.6 & $8,200,000$ & $36 \%$ & $13,036,320$ & $56.94 \%$ \\
\hline \multicolumn{9}{|l|}{ Middle East } \\
\hline Israel & $7,473,052$ & $5,263,146$ & $70.40 \%$ & 11.3 & $3,100,000$ & $44 \%$ & $3,739,440$ & $50.85 \%$ \\
\hline U.A.E & $5,148,664$ & $3,555,100$ & $69.00 \%$ & 27.6 & $*$ & $*$ & $3,370,780$ & $67.75 \%$ \\
\hline \multicolumn{9}{|l|}{ Europe } \\
\hline Norway & $4,691,849$ & $4,560,572$ & $97.20 \%$ & 151.3 & $2,100,000$ & $43 \%$ & $2,760,680$ & $55.37 \%$ \\
\hline Russia & $138,739,892$ & $61,472,011$ & $44.30 \%$ & 31.9 & $25,000,000$ & $18 \%$ & $7,585,740$ & $5.39 \%$ \\
\hline Turkey & $78,785,548$ & $35,000,000$ & $44.40 \%$ & 33.9 & $8,300,000$ & $11 \%$ & $32,438,200$ & $41.69 \%$ \\
\hline \multicolumn{9}{|c|}{ European Union } \\
\hline Belgium & $10,431,477$ & $8,489,901$ & $81.40 \%$ & 131.1 & $3,000,000$ & $28 \%$ & $4,923,480$ & $47.33 \%$ \\
\hline Finland & $5,259,250$ & $4,661,265$ & $88.60 \%$ & 118.4 & $2,300,000$ & $43 \%$ & $2,267,140$ & $43.23 \%$ \\
\hline France & $65,102,719$ & $50,290,226$ & $77.20 \%$ & 78.6 & $18,800,000$ & $30 \%$ & $25,307,820$ & $39.07 \%$ \\
\hline Germany & $81,471,834$ & $67,364,898$ & $82.70 \%$ & 74.8 & $23,000,000$ & $28 \%$ & $25,050,580$ & $30.62 \%$ \\
\hline Greece & $10,760,136$ & $5,043,550$ & $46.90 \%$ & 26.0 & $3,900,000$ & $35 \%$ & $3,971,980$ & $36.11 \%$ \\
\hline Ireland & $4,670,976$ & $3,122,358$ & $66.80 \%$ & 69.0 & $1,600,000$ & $35 \%$ & $2,225,720$ & $48.15 \%$ \\
\hline Italy & $61,016,804$ & $35,800,000$ & $58.70 \%$ & 60.8 & $22,800,000$ & $38 \%$ & $23,028,220$ & $38.16 \%$ \\
\hline Netherlands & $16,847,007$ & $15,071,191$ & $89.50 \%$ & 162.5 & $6,300,000$ & $38 \%$ & $7,516,620$ & $45.16 \%$ \\
\hline Poland & $38,441,588$ & $23,852,486$ & $62.00 \%$ & 40.2 & $7,100,000$ & $19 \%$ & $10,253,960$ & $26.63 \%$ \\
\hline Portugal & $10,760,305$ & $5,455,217$ & $50.70 \%$ & 135.3 & $3,700,000$ & $35 \%$ & $4,706,960$ & $44.09 \%$ \\
\hline Romania & $21,904,551$ & $8,578,484$ & $39.20 \%$ & 114.5 & $2,900,000$ & $14 \%$ & $5,679,800$ & $25.87 \%$ \\
\hline Spain & $46,754,784$ & $30,654,678$ & $65.60 \%$ & 64.1 & $20,800,000$ & $46 \%$ & $16,918,200$ & $36.38 \%$ \\
\hline Sweden & $9,088,728$ & $8,441,718$ & $92.90 \%$ & 244.4 & $4,800,000$ & $52 \%$ & $4,788,120$ & $52.94 \%$ \\
\hline UK & $62,698,362$ & $52,731,209$ & $84.10 \%$ & 116.1 & $25,000,000$ & $40 \%$ & $32,175,460$ & $51.61 \%$ \\
\hline
\end{tabular}


Table 2 provides a break-down of potential online activity in each country where Groupon currently operates. The countries are categorised according to the same geographical regions as in Table 1 . Table 2 provides a population estimate for each country and indicates the percentage of the population that has access to the Internet, as well as the number of smartphone users and the number of active Facebook profiles. From Table 1, it is evident that some countries lack the necessary electricity supply and number of fixed telephone lines required for sustainable Internet activity. An alternative solution to a lack of telephone lines is through mobile broadband or smartphones that provide users with access to the Internet right in the palm of their hands. Owning a mobile phone does not guarantee access to the Internet, though. This can only happen through a smartphone equipped with the software to enable that kind of functionality. Thus, it becomes necessary to determine whether customers from markets with limited land line connectivity might have access to an alternative form of connectivity to the Internet via mobile broadband and their smartphones. The percentage of mobile broadband connections and the number of smartphone users in a particular population becomes significant.

Irrespective of the platform used to access the Internet, Internet bandwidth serves as a significant indicator of online activity since the speed of the Internet would affect the ease of use. Hong Kong, Singapore and Sweden have the highest smartphone penetration of all the countries in which Groupon operates. These countries are also at the top of the list in terms of Internet bandwidth. Bandwidth refers to "the volume of information per unit of time that a transmission medium, such as an Internet connection, can accommodate" (Fisher, 2013) and is usually measured in kilobytes per second $(\mathrm{kb} / \mathrm{s})$. Using the analogy of a pipe with water running through it, the size of the pipe determines the speed at which water flows through. As the bandwidth increases, so does the amount of data that can flow through at any given time (Fisher, 2013). This would increase downloading speed, for instance. Hong Kong is at the top of the list with Internet bandwidth of $964.6 \mathrm{~kb} / \mathrm{s}$. Singapore is second with $547.1 \mathrm{~kb} / \mathrm{s}$ and Sweden is fourth on the global list with $244.4 \mathrm{~kb} / \mathrm{s}$.

In comparison, China, India, Indonesia, Mexico and Peru all have bandwidth speeds below $10 \mathrm{~kb} / \mathrm{s}$. The extent of the disparity between the nations on the top of the list and the nations at the bottom of the list is staggering. Countries like South Africa, Japan, Malaysia, South Korea, Taiwan, Israel, U.A.E., Russia, Turkey, Greece, Poland, Argentina, Brazil, Chile, Columbia and New Zealand all have bandwidth speeds that are much slower than the USA. If people in the USA can access Groupon comfortably with their level of bandwidth (on $47.2 \mathrm{~kb} / \mathrm{s}$ and a ranking of $33^{\text {rd }}$ in the world), picture the challenge faced by consumers in these markets with half the bandwidth capacity and often only one-third of the Internet saturation levels.

According to Meeker (cited by Duncan, 2012), mobile devices running iOS and Android now account for $45 \%$ of browsing compared to just 35\% for Windows machines, pointing to rapidly expanding access to the Internet through mobile devices. Some countries have expanded their mobile broadband, thus priming their economies to move from an efficiency-based focus to the next stage of innovation. Connecting to the Internet through smartphones still presents limitations to latency and throughput, thus pointing to the fact that a lack of certain infrastructure cannot be fully circumvented by the introduction of new technologies since there still has to be some form of existing broader telecommunications backbone. The speed of smartphone connectivity via mobile broadband is still dependent on fixed line infrastructure, including fibre-optic cables and satellites. Although wireless technologies have significantly reduced the infrastructure costs related to expanding access to the Internet, by eliminating the need to invest in "the last mile" of fibre-optic cables from the infrastructure backbone to a user's home (Rouse, 2005), these costs cannot be eradicated completely. Furthermore, smartphone technology enables access to data-rich websites like Facebook and Groupon, again limiting full access to the Internet to smartphone users and excluding a vast majority of other mobile phone users.

Several countries listed in Table 2 have limited internet saturation, indicating that only a small percentage of the population actually has access to the Internet and therefore to e-commerce and the products and services offered through social group buying. With the exception of Malaysia (with 61.7\% Internet saturation) and Poland (with 62\% Internet saturation), none of the countries in Stage 1 or 2 of economic development have an Internet saturation rate higher than 55\%, which means that in these countries, almost half of the population does not have access to the Internet. It could be argued that for an e-commerce business model to be lucrative, it should be possible for an online company to access at least $60 \%$ of the target market. In countries like South Africa (13.9\%), China (38\%), India (10.2\%), Indonesia (22.4\%), Romania (39.2\%), Mexico (36.9\%) and Peru (34.1\%), the Internet 
saturation is less than $40 \%$. In these markets, Groupon would have access to approximately $10 \%$ to $30 \%$ of the population since more than $60 \%$ of the population does not have access to the Internet. Even in some of the developed economies that are in Stage 3 of development, the Internet saturation rates are lower than $60 \%$ - for example, in Russia (44.3\%), Turkey (44.4\%), Greece (46.9\%), Italy (58.7\%), Portugal (50.7\%), Brazil (39\%), Chile $(59.2 \%)$ and Puerto Rico $(42.6 \%)$.

As mentioned already, it is possible for consumers to access the Internet through other channels such as mobile broadband and smartphones. Mobile broadband subscriptions for countries in Stage 1 or 2 of economic development are still very low. For example, India is in Stage 1 of economic development and has a mere 1.9 mobile broadband subscriptions per 100 people in the population (1.9/100) (Schwab \& Sala-i-Martin, 2012, p. 494). The mobile broadband subscriptions for countries in Stage 2 of economic development are not much better - with South Africa at 19.8/100, China at 9.5/100, Indonesia at 22.2/100, Malaysia at 12.3/100, Romania at 14.1/100, Mexico at 4.6/100, Columbia at 3.7/100, and Peru at 1.4/100. (A list of Mobile Broadband Subscriptions is available upon request from the authors.)

Looking at the smartphone penetration in the markets with low Internet saturation rates, the majority of countries have smartphone penetration rates below 20\% (South Africa, China, India, Indonesia, Russia, Turkey, Romania, Mexico and Brazil). No statistics were available for Peru and Puerto Rico. The only exceptions are Greece (with 35\% smartphone penetration), Italy (with 38\%) and Portugal (with 35\%). Even though these markets have slightly higher smartphone penetration rates, it is still below $40 \%$ and thus still presenting e-commerce businesses with limited access to their target markets.

Social group buying is an extension of social media. Until recently, Groupon advertised extensively on Facebook to attract potential coupon users by driving e-mail signups and selling daily deals. Groupon's advertising expenditure was exclusively managed by a company called AdParlor who markets themselves as a platform for making social network advertising easy (Constine, 2011). In effect, Groupon thus outsourced its core business to AdParlor. Transitioning from customer acquisition to customer activation, Groupon decided to no longer advertise on Facebook in order to cut its marketing costs. It decided that it has enough customers for now, switching from attracting new customers to wringing value out of existing subscribers (Bercovici, 2012). The customer base that Groupon has managed to attract is disproportionally located. The unanswered question here is, "What about customers in developing markets?" These customers still have limited access to the Internet and it is highly unlikely that they are aware of all the Groupon deals being offered. Just because Groupon has attracted a sufficient number of customers in the developed markets, does not mean that they can now ignore the customers in the developing markets, since they have expanded their business to these markets. Perhaps Facebook advertisements with Groupon deals in these markets are still necessary.

Active Facebook profiles in developing markets are indicative of consumers' online activity and their level of comfort in using social media, since social group buying is an extension of social media. The countries with the lowest Facebook penetration are China (with 0.04\%), India (with 5.37\%) and Russia (with 5.39\%). USA-based electronic companies have struggled to gain access to the Chinese market due to political reasons, such as the censorship enforced by the Chinese government (Vaitheeswaran, 2013). These markets also represent cultural barriers due to significant differences in values between the USA and these countries. Even in light of these differences, the rate of Facebook penetration as an indicator of social media activity in these markets does not bode well for Groupon. Additionally, these three countries form part of the BRICS (Brazil, Russia, India, China and South Africa) grouping of emerging economies (The Economist, 2008; Van Agtmael, 2007). While Groupon rushed with the rest of the world to invest in these countries due to the promised pay-off of high growth and high return on investment, the truth has not been as inspiring as the marketing campaign. Although these markets are delivering high returns on investment, the majority of the growth is in commodities and manufacturing and not from innovation-based products as one would expect from Stage 3 economies like the USA. As e-commerce is a manifestation of an innovation-based economy the actual focus of these economies goes some way in explaining Groupon's mediocre performance in these markets. South Africa (in Africa) and Indonesia, Japan and South Korea (in Asia) all have Facebook penetration rates below 20\%. Japan is a Stage 3 economy and South Africa, Indonesia and South Korea are all regarded as high growth economies. Low social media activation in these markets is a troubling challenge for social group buying entities, like Groupon, to overcome. 


\section{CONCLUSION}

The speed at which Groupon was acquiring imitator companies in other markets did not allow for the establishment of proper synergistic operations. Rather than focusing on improving its technology, Groupon was struggling to deploy its basic platform across all of its foreign markets and is consequently running on dozens of incompatible platforms. No doubt, the effect of entering markets that are vastly different in terms of infrastructure and technological development compared to its home market. Despite infrastructure and technological advancement in the European market being the most similar to the USA, Groupon has experienced some of their biggest losses in sales and growth in these markets. Groupon has also had to write down the value of its assets in China (Popper, 2013). In extreme cases, there are reports of foreign operations making sales calls and sending spreadsheets back to Chicago without using the Groupon e-commerce platform at all (Popper, 2013). These cases testify to the challenges that developing economies face in catching up with technological advancement and business practices. Often their infrastructure and level of technological readiness constrain their pace of progression in e-commerce activities.

In countries with limited access to the Internet, Groupon has not managed to build an extensive database of customers. Although they may have reached a particular level of customer saturation in the USA, it cannot be argued that they have succeeded in building the same extensive network of customers in other markets, which calls into question the spending on acquisitions in other markets in order to expand their global reach.

High-tech companies planning to invest in foreign markets should carefully consider the reasons and potential return on investment of investing in specific developing markets. Emerging market growth does not equate to innovation readiness. Markets that are racing to catch up with technology might not be equipped to sustain ecommerce business activities without a fully developed broader telecommunications backbone to support online activity. In the famous words of Richard Branson (1993), "Growth does not always lead a business to build on success. All too often, it converts a highly successful business into a mediocre large business."

\section{AUTHOR INFORMATION}

Suzaan Hughes is a lecturer in the Department of Management within the School of Business and Economics at Monash University, South Africa. Her research interests include strategic management, management education, leadership, managerial communication, event management and coaching and mentoring. E-mail: suzaan.hughes@monash.edu (Corresponding author)

Chantal Breytenbach is a lecturer in the Department of Management within the School of Business and Economics at Monash University, South Africa. Her research interests include strategic management, management education, leadership and motivation, organisational behaviour, health and wellbeing and coaching and mentoring. E-mail: chantal.breytenbach@monash.edu

\section{REFERENCE LIST}

1. Amihud, Y., Dodd, P. \& Weinstein, M. (1986). Conglomerate mergers, managerial motives, and stockholder wealth. Journal of Banking \& Finance, 10, 401-410.

2. Bercovici, J. (2012). Groupon's evolution is hurting Facebook (but helping Google). Forbes, May. Retrieved on 2013-05-01 from: http://www.forbes.com/sites/jeffbercovici/2012/06/05/groupons-evolutionis-hurting-facebook-but-helping-google/

3. Berry, J. W. (1980). Social and cultural change. In H. C. Triandis \& R.W. Brislin (Eds.), Handbook of cross-cultural psychology (Vol. 5, pp. 211-279). Boston: Allyn \& Bacon.

4. Beukes, C. \& Hughes, S. (2012). An investigation of mergers and acquisitions as the growth and globalization strategy for Groupon. World Review of Business Research, 2(5), 108-127.

5. Birkinshaw, J., Bresman, H. \& Hakanson, L. (2000). Managing the post-acquisition integration process: How the human integration and task integration processes interact to foster value creation. Journal of Management Studies, 37, 395-425.

6. Bradley, M., Desai, A. \& Kim, E. H. (1983). The rationale behind inter-firm tender offers: Information or synergy? Journal of Applied Corporate Finance, 16, 63-76. 
7. Branson, R. (1993, May). Growing bigger while still staying small. [Speech at the Institute of Directors]. London.

8. Bruner, R. (2004a). Applied mergers and applications. New York: John Wiley \& Sons.

9. Bruner, R. (2004b). Where M\&A pays and where it strays: A survey of the research. Journal of Applied Corporate Finance, 16, 63-76.

10. Buono, A. F. \&Bowditch, J. L. (1989). The human side of mergers and acquisitions. San Francisco: JosseyBass.

11. Cartwright, S. \& Schoenberg, R. (2006). Thirty years of mergers and acquisitions research: Recent advances and future opportunities. British Management Journal, 17, S1-S5.

12. Chakrabarti, A., Hauschildt, J. \& Süverkrüp, C. (1994). Does it pay to acquire technological firms? $R \& D$ Management, 24(1), 47-56.

13. Collan, M. \& Kinnunen, J. (2011). A procedure for the rapid pre-acquisition screening of target companies using the pay-off method for real option valuation. Journal of Real Options \& Strategy, 4(1), 117-141.

14. Constine, J. (2011). Groupon signs exclusively with AdParlor for Facebook ads. Inside Facebook. Accessed on 2013-05-09 from: http://www.insidefacebook.com/2011/03/17/groupon-adparlor-ads-api/

15. DePamphilis, D. (2009). Mergers, acquisitions and other restructuring activities. USA: Elsevier.

16. Dictionary.com. (2013). Infrastructure. Accessed 2013-03-22 from: www.dictionary.com.

17. Dictionary.com (2013). Throughput. Accessed 2013-05-01 from: http://dictionary.reference.com/browse/throughput

18. Duncan, G. (2012). What happens to the web now that smartphones and tablets run the show? Digital Trends, December. Retrieved on 2013-05-01 from: http://www.digitaltrends.com/mobile/get-used-to-itmobile-is-taking-over-the-internet/

19. Edwards, M. R. \& Edwards, T. (2012). Company and country effects in international mergers and acquisitions: Employee perceptions of a merger in three European countries. Economic and Industrial Democracy, 33, 505-529. DOI: 10.1177/0143831X11421685. Available online from: http://eid.sagepub.com/content/33/3/505

20. Elsass, P. \& Veiga, J. (1994). Acculturation in acquired organizations: A force-field perspective. Human Relations, 47, 431-453.

21. Eriksson, P. \& Kovalainen, A. (2008). Qualitative Methods in Business Research. London: Sage.

22. Fisher, T. (2013). Bandwidth. About.com. Accessed on 2013-05-09 from: http://pcsupport.about.com/od/termsb/g/bandwidth.htm

23. Fowler, K. L. \& Schmidt, D. R. (1988). Tender offers, acquisitions, and subsequent performance in manufacturing firms. Academy of Management Journal, 31, 962-974.

24. Schwab, K., Sala-i-Martin, X. \& Greenhill, R. (2011). The Global Competitiveness Report. World Economic Forum, Geneva Switzerland.

25. Gomm, R. Hammersley, M. \& Foster, P. (Eds.) (2000). Case study method: Key issues, key texts. London: Sage.

26. Habelian, J., Devers, C., McNamara, G., Carpenter, M. \& Davison, R. (2009). Taking stock of what we know about mergers and acquisitions: A review and research agenda. Journal of Management, 35(3), 469502 .

27. Hagedoorn, J. \& Duysters, G. (2002). The effect of mergers and acquisitions on the technological performance of companies in a high-tech environment. Technology Analysis \& Strategic Management, 14(1), 67-85.

28. Hesse-Biber, S. N. \& Leavy, P. (2011). The practice of qualitative research. $\left(2^{\text {nd }}\right.$ ed.). Thousand Oaks, California: Sage.

29. Hitt, M. A., Harrison, J. S. \& Ireland, D. R. (2000). Mergers \& acquisitions: A guide to creating value for stakeholders. New York: Oxford University Press.

30. Hitt, M. A., Hoskisson, R. E., Johnson, R. A. \& Moesel, D. D. (1996). The market for corporate control and firm innovation. Academy of Management Journal, 39, 1084-1119.

31. Ikedo, K. \& Doi, N. (1983). The performance of merging firms in Japanese manufacturing industry: 19641975. Journal of Industrial Economics, 31, 257-266.

32. King, D. R., Dalton, D. R., Daily, C. M. \& Covin, J. G. (2004). Meta-analyses of post- acquisition performance: Indications of unidentified moderators. Strategic Management Journal, 25, 187-200. 
33. Krishnamurti, C. \& Vishwanath, S. R. (2008). Mergers, acquisitions and corporate restructuring. Los Angeles: Sage.

34. Lawton, C. (2011). Nokia's pain becomes Finland's. The Wall Street Journal, June. Retrieved on 2013-0501 from: http://online.wsj.com/article/SB10001424052702304563104576359743926525676.html

35. Link, A. N. (1988). Acquisitions as sources of technological innovation. Mergers and Acquisitions, 23(3), 36-39.

36. Lubatkin, M. \& O'Neil, H. M. (1987). Merger strategies and capital market risk. Academy of Management Journal, 30, 665-684.

37. MacDonald, J. M. (1985). R\&D and the directions of diversification. Review of Economics and Statistics, 47, 583-590.

38. McAfee, A. \& Brynjolfsson, E. (2008). Investing in the IT that makes a competitive difference. Harvard Business Review, 86(7/8), 98-107.

39. Merriam, S. B. (2009). Qualitative Research: A guide to design and implementation. San Francisco, California: Jossey-Bass.

40. Mitchell, B. (2013). Network bandwidth and latency. About.com. Retrieved on 2013-05-01 from: http://compnetworking.about.com/od/speedtests/a/network_latency.htm

41. Myeong-Gu, S. \& Hill, N. S. (2005). Understanding the human side of merger and acquisition: An integrative framework. Journal of Applied Behavioural Science, 41, 422-443. DOI:

10.1177/0021886305281902. Available online from: http://jab.sagepub.com/content/41/4/422

42. Nahavandi, A. \& Malekzadeh, A. L. (1988). Acculturation in mergers and acquisitions. Academy of Management Review, 13, 79-90.

43. Napier, N. (1989). Mergers and acquisitions, human resource issues and outcomes: A review and suggested typology. Journal of Management Studies 26(3), 271-289.

44. Ooghe, H., Van Laere, E. \& De Langhe, T. (2006). Are acquisitions worthwhile? An empirical study of the post-acquisition performance of privately held Belgian companies. Small Business Economics, 27, 223-243.

45. Oster, S. M. (1994). Modern competitive analysis. New York: Oxford University Press.

46. Pablo, A. L. \& Javidan, M. (2004). Mergers and acquisitions: Creating integrative knowledge. Oxford: Blackwell.

47. Popper, B. (2013). Greed is Groupon: Can anyone save the company from itself? The Verge. Accessed on 2013-05-09 from: http://www.theverge.com/2013/3/13/4079280/greed-is-groupon-can-anyone-save-thecompany-from-itself

48. Randall, T. (2012). India's blackout fix leaves 400 million without power. Bloomberg, August. Retrieved on 2013-05-01 from: http://www.bloomberg.com/news/2012-08-01/india-s-blackout-fix-leaves-400million-without-power.html

49. Rossi, M., Tarba, S. Y. \& Raviv, A. (2012). Mergers and acquisitions in the high-tech industry: A literature review. International Journal of Organizational Analysis, 21(1).

50. Rouse, M. (2005). Last mile technology. SearchNetworking. Accessed on 2013-05-09 from: http://searchnetworking.techtarget.com/definition/last-mile-technology

51. Ruess, M. \& Voelpel, S. C. (2012). The PMI Scorecard: A tool for successfully balancing the post-merger integration process. Organizational Dynamics, 41, 78-84.

52. Sala-i-Martín, X. \& Artadi, E. V. (2004). The Global Competitiveness Index. The Global Competitiveness Report 2004-2005. Hampshire: Palgrave Macmillan. 51-80.

53. Schwab, K. \& Sala-i-Martin, X. (2012). The Global Competitiveness Report: 2012-2013. World Economic Forum. Geneva, Switzerland: SRO-Kundig. Accessed on 2013-04-02 from: http://www.weforum.org/reports/global-competitiveness-report-2012-2013

54. Schwab, K., Sala-i-Martin, X. \& Greenhill, R. (2011). The Global Competitiveness Report: 2011-2012. World Economic Forum. Geneva, Switzerland: SRO-Kundig. Accessed on 2013-04-02 from: http://www3.weforum.org/docs/WEF GCR Report 2011-12.pdf

55. Stake, R. (2005). Qualitative studies. In N. K. Denzin \& Y. S. Lincoln (Eds.), The Sage Handbook of qualitative research ( $3^{\text {rd }}$ ed.). (pp. 443-465). Thousand Oaks, California: Sage.

56. Styan, J. B. (2013). Lowdown on load shedding. Fin24, March. Accessed on 2013-05-01 from: http://m.news24.com/fin24/Companies/Industrial/The-lowdown-on-load-shedding-20130423

57. Sullivan, A. \& Sheffrin, S. M. (2003). Economics: Principles in action. Upper Saddle River, New Jersey: Pearson Prentice Hall. 
58. Teerikangas, S. \& Very, P. (2006). The culture performance relationship in mergers and acquisitions: From yes/no to how. British Journal of Management 17, S7-S49.

59. The Economist. (2008). Acronyms BRIC out all over. The Economist. Accessed on 2013-05-09 from: http://www.economist.com/node/12080703?story_id=12080703

60. United Nations. (2009). World Investment Report. New York: United Nations.

61. Vaitheeswaran, V. V. (2013). Mr. Kim, tear down that wall; Mr. Xi, carry on. The Economist. January. Accessed on 2013-05-09 from: http://www.economist.com/blogs/analects/2013/01/google-china

62. Van Agtmael, A. (2007). The emerging markets century: How a new breed of world-class companies is overtaking the world. New York, New York: Free Press.

63. Walker, M. M. (2000). Corporate takeovers, strategic objectives and acquiring-firm shareholder wealth. Financial Management, 29, 53-55.

64. Wang, Y. (2013). More people have cell phones than toilets: U.N. study shows. Time Newsfeed, March. Accessed on 2013-04-02 from: http://newsfeed.time.com/2013/03/25/more-people-have-cell-phones-thantoilets-u-n-study-shows/?xid=newsletter-europe-weekly

65. Wauters, R. (2011). No Groupon in India: Company rolls out "Crazeal" in eleven cities. Crunchbase, October. Retrieved on 2013-05-01 from: http://techcrunch.com/2011/10/03/no-groupon-in-india-companyrolls-out-crazeal-in-11-cities/

66. Weber, Y. (1996). Corporate cultural fit and performance in mergers and acquisitions. Human Relations 49(9), 1181-1202.

67. Yin, R. K. (2008). Case study research: Design and methods. ( $4^{\text {th }}$ ed.). Thousand Oaks, California: Sage.

68. Zuma, J. (2011). Statement by President Jacob Zuma, marking the 50 day countdown to sensus 2011. Press Statement. Retrieved on 2013-05-01 from: http://www.statssa.gov.za/census2011/StatementPresident.asp 